\title{
Molecular detection of disseminated tumor cells in the peripheral blood of patients with gastric cancer: Evaluation of their prognostic significance
}

\author{
C.H. Wu ${ }^{a}$, S.R. Lin ${ }^{a}$, J.S. Hsieh ${ }^{b}$, F.M. Chen ${ }^{\mathrm{a}, \mathrm{b}}$, C.Y. Lu ${ }^{\mathrm{c}}$, F.J. Yuc, T.L. Cheng ${ }^{\mathrm{d}}$, T.J. Huang ${ }^{\mathrm{b}}$, \\ S.Y. Huang ${ }^{\mathrm{e}}$ and J.Y. Wang ${ }^{\mathrm{a}, \mathrm{b}, *}$ \\ ${ }^{a}$ MedicoGenomic Research Center, Kaohsiung Medical University, Kaohsiung, Taiwan \\ ${ }^{\mathrm{b}}$ Department of Surgery, Kaohsiung Medical University, Kaohsiung, Taiwan \\ ${ }^{\mathrm{c}}$ Department of Internal Medicine, Kaohsiung Medical University, Kaohsiung, Taiwan \\ ${ }^{\mathrm{d}}$ School of Biomedical Science and Environmental Biology, Kaohsiung Medical University, Kaohsiung, Taiwan \\ e Asia Hepato Gene Co., Ltd., Kaohsiung, Taiwan
}

\begin{abstract}
Early detection of disseminated tumor cells in the peripheral blood of patients with early stage gastric cancer could help to improve the outcome after tumor resection. The aim of this study is to evaluate the prognostic significance of tumor-related mRNA for the detection of circulating tumor cells in gastric cancer patients by a reverse-transcriptase polymerase chain reaction (RT-PCR) method. We simultaneously analyzed human telomerase reverse transcriptase (hTERT), cytokeratin-19 (CK-19), cytokeratin-20 (CK-20) and carcinoembryonic antigen (CEA) mRNA (messenger RNA) expression in the peripheral blood of 42 gastric cancer patients and 30 healthy individuals. Additionally, analyses were carried out for the correlation of these four molecular markers with patients' clinicopathologic features, as well as the occurrence of postoperative recurrence/metastasis. Among 42 gastric cancer patients, the prevalence of mRNA for hTERT, CK-19, CK-20, and CEA was 61.9\% (26/42), 69\% (29/42), 61.9\% (26/42), and 78.6\% (33/42), respectively. All 30 healthy individuals were negative for hTERT and CEA mRNA, while two were positive for either CK-19 mRNA or CK-20 mRNA. Positive CEA mRNA was significantly correlated with tumor size $(p=0.008)$, vessel invasion $(p=0.001)$, depth of tumor invasion $(p=0.007)$, lymph node metastasis $(p<0.001)$, and TNM stage $(p<0.001)$. In addition, the multivariate logistic regression demonstrated that CEA mRNA expression was an independent and significant predictor for postoperative recurrence/metastasis $(p=0.032)$. Our findings suggest that CEA mRNA may be a more reliable marker than hTERT, CK-19 and CK-20 for the detection of circulating cancer cells in gastric cancer patients' peripheral blood. Patients with positive CEA mRNA expression in peripheral blood have a significantly higher risk of postoperative recurrence/metastasis.
\end{abstract}

Keywords: Molecular detection, disseminated tumor cell, gastric cancer, CEA mRNA

${ }^{*}$ Corresponding author: Jaw-Yuan Wang, M.D., Ph.D., Department of Surgery and MedicoGenomic Research Center, Kaohsiung Medical University, No. 100, Shih Chuan 1st Road, Kaohsiung 807, Taiwan. Tel.: +886 7 3122805; Fax: +886 7 3114679; E-mail: cy614112@ms14.hinet.net.

\section{Introduction}

Gastric cancer remains one of the most prevalent malignant tumors in Taiwan and throughout the world [1]. Although recent advances in the treatment of gastric cancer have provided improvement in clinical outcome of patients [2-5], the prognosis of patients with ad- 
vanced stages of this disease is unfavorable due to the high incidence of metastases and recurrence. Since early detection is an important factor contributing to reduction of cancer mortality, the development of a sensitive, specific and convenient diagnostic method for detecting gastric cancer at a very early stage is an issue of utmost importance. Models of metastasis indicate that primary tumor cells spread to other organs via circulation (blood and lymphatics). With the development of techniques in molecular biology, circulating tumor cells are now easily detectable by using polymerase chain reaction (PCR) or reverse transcriptase-polymerase chain reaction (RT-PCR).

Recently, DNA and mRNA have been used to detect the disseminated tumor cells in cancer diagnosis strategies [6,7]. With respect to gastric cancers, DNA is detected by PCR of genes with genetic alteration such as APC, k-ras and p53 [8-10], and mRNA is detected by RT-PCR, including cancer cell- or tissue-specific transcripts such as human telomerase reverse transcriptase (hTERT), mucin 1, c-met, cytokeratin-19 (CK-19), cytokeratin-20 (CK-20) and carcinoembryonic antigen (CEA) [11-15]. RT-PCR is effective in the detection of disseminated tumor cells in the peripheral circulation. This information may add to the established staging system, helping to define cancer status and predict the prognosis of patients with malignancy more precisely. There have been no previous reports simultaneously analyzing mRNA molecular markers of hTERT, CK-19, CK-20, and CEA for the detection of circulating tumor cells in human gastric cancer. In the present study, we analyze mRNA profiles of hTERT, CK-19, CK-20, and CEA in peripheral blood samples from gastric cancer patients, and explore the association between the presence of these four molecular markers and a variety of clinicopathological features. Eventually, these markers could be involved in a potential noninvasive approach, used to identify patients at a higher risk of postoperative recurrence/metastasis.

\section{Materials and methods}

Forty-two patients undergoing elective surgery for gastric cancer at the Department of Surgery of Kaohsiung Medical University Hospital between August 2002 and December 2003 enrolled in this study. Twenty-four were males, and 18 were females. The mean age was 60.2 years (range, 34-84). A 4-ml sample of peripheral blood was obtained from each gastric cancer patient during the surgical resection of the tumor or during pal- liative surgery. In addition, peripheral blood samples taken from 30 healthy individuals served as controls. To prevent contamination of epithelial cells, peripheral blood samples were obtained through a catheter inserted into a peripheral vessel, and the first $5 \mathrm{ml}$ of blood was discarded. Written informed consent was obtained from all subjects and/or guardians for the use of the subjects' blood samples. Sample acquisition and subsequent use were also approved by the Institutional Review Board of Kaohsiung Medical University. Clinical stages and pathological features of primary tumors were defined according to the criteria of the American Joint Commission on Cancer [16].

\subsection{Total RNA isolation and first strand cDNA synthesis}

Total RNA was extracted from fresh whole blood of gastric cancer patients by using a QIAamp ${ }^{\circledR}$ RNA Blood Mini Kit (QIAGEN Inc., Valencia, CA, USA) according to the manufacturer's instructions. The RNA concentration was determined spectrophotometrically on the basis of absorbance at $260 \mathrm{~nm}$. First strand cDNA was synthesized from total RNA by using a RTPCR kit (Promega Corp., Madison, WI, USA). The reverse transcription was carried out in a reaction mixture consisting of $1 \times$ Transcription Optimized $5 \times$ Buffer, $25 \mu \mathrm{g} / \mathrm{ml}$ Oligo(dT) 15 Primer, $100 \mathrm{mmol} / \mathrm{L}$ PCR Nucleotide Mix, $200 \mu \mathrm{mol} / \mathrm{L}$ MLV Reverse Transcriptase, and $25 \mu$ l Recombinant RNasin ${ }^{\circledR}$ Ribonuclease Inhibitor. The reaction mixtures with RNA were incubated at $42^{\circ} \mathrm{C}$ for longer than 2 hours, heated to $95^{\circ} \mathrm{C}$ for 5 minutes, and then stored at $4{ }^{\circ} \mathrm{C}$ until analysis.

\subsection{Multiplex RT-PCR}

The target genes for PCR detection included hTERT, CK19, CK20 and CEA. Sequences of the oligonucleotide primers were designed according a PCR primer selection program based on xprimer at http://alces.med.umn.edu/rawprimer.html. In addition, glyceraldehyde-3-phosphate dehydrogenase (GADPH) primers were added as internal controls to correct for the differences in total RNA amounts between the gastric cancer patients and healthy individuals. Each reaction mixture contained 1X PCR buffer $(10 \mathrm{mmol} / \mathrm{L}$ Tris-HCL, pH 8.3, $50 \mathrm{mmol} / \mathrm{L} \mathrm{KCL}, 2 \mathrm{mmol} / \mathrm{L} \mathrm{MgCl}_{2}$ ), $50 \mu \mathrm{mol} / \mathrm{L} \mathrm{dNTP}, 0.1 \mu \mathrm{mol} / \mathrm{L}$ sense and antisense primers for target genes and $0.01 \mu \mathrm{mol} / \mathrm{L}$ sense and antisense primers for GADPH, and 2.5 U Taq DNA polymerase in a total volume of $50 \mu \mathrm{l}$. PCR ampli- 
Table 1

List of all primers used with PCR amplification conditions in the study

\begin{tabular}{lllc}
\hline Primer & $5^{\prime}-3^{\prime}$ sequence & PCR conditions & Size of PCR (bp) \\
\hline hTERT (sense) & AAG TTCCTGCACTGGCTGAT & $\left(94^{\circ} \mathrm{C} / 20 \mathrm{~s}, 60^{\circ} \mathrm{C} / 10 \mathrm{~s}, 74^{\circ} \mathrm{C} / 20 \mathrm{~s}\right) \times 35$ & 265 \\
hTERT (antisense) & CACGACGTAGTCCATGTTCA & & \\
CK-19 (sense) & ATGAAAGCTGCCTTGGAAGA & $\left(94^{\circ} \mathrm{C} / 20 \mathrm{~s}, 60^{\circ} \mathrm{C} / 10 \mathrm{~s}, 74^{\circ} \mathrm{C} / 20 \mathrm{~s}\right) \times 33$ & 138 \\
CK-19 (antisense) & TGATTCTGC-CGCTCACTATCAG & & \\
CK-20 (sense) & CTGAATAAGGTCTTTGATGACC & $\left(94^{\circ} \mathrm{C} / 20 \mathrm{~s}, 60^{\circ} \mathrm{C} / 10 \mathrm{~s}, 74^{\circ} \mathrm{C} / 20 \mathrm{~s}\right) \times 35$ & 138 \\
CK-20 (antisense) & ATGCTTGTGTAGGCCATCGA & & 138 \\
CEA (sense) & AACTGGTGT- CCCGGATATCA & $\left(94^{\circ} \mathrm{C} / 20 \mathrm{~s}, 60^{\circ} \mathrm{C} / 10 \mathrm{~s}, 74^{\circ} \mathrm{C} / 20 \mathrm{~s}\right) \times 34$ & 165 \\
CEA (antisense) & ATATTCTTTGCTCCTTGCCA & & \\
GADPH (sense) & CCTCAAGATCATCAGCAATGC & $\left(94^{\circ} \mathrm{C} / 20 \mathrm{~s}, 60^{\circ} \mathrm{C} / 10 \mathrm{~s}, 74^{\circ} \mathrm{C} / 20 \mathrm{~s}\right) \times 35$ & \\
GADPH (antisense) & GGAAACTGTGGC- GTGATGG & & \\
\hline
\end{tabular}

fication was carried out in a programmable thermal cycler (Primus 25, MWG-BIOTECH AG, Ebersberg, Germany). The cycle was repeated independently of the results of the PCR cycle number quality control test. PCR products were analyzed in 3\% agarose gel. The signals on UV transilluminator were scanned with a computing laser densitometer (Alpha Inotech, San Leandro, CA, USA). The sequences of primers, PCR conditions and sizes of PCR products are listed in Table 1 .

\subsection{Clinical follow-up results}

All the patients were followed up regularly at threemonth intervals. At each visit, physical examinations, routine blood work, serum CEA measurement and liver function tests were conducted as appropriate. Chest Xrays and abdominal ultrasonography were performed every six months. Computed tomography or magnetic resonance imaging was carried out if indicated. With a median follow-up of 18 months (range, 10-26), the correlation between the development of clinical metastases/recurrence and the detection of individual molecular markers was analyzed.

\subsection{Statistical analysis}

All data were analyzed using the Statistical Package for the Social Sciences, version 10.0 (SPSS Inc., Chicago, IL). Data were presented as mean \pm SE. The two-sided Pearson $\chi^{2}$ test and the Fisher exact test were used to compare the clinicopathological parameters between mRNA marker-positive patients and mRNA marker-negative patients. To clarify the clinical significance of these mRNA markers as the predictors of postoperative recurrence/metastasis, multivariate adjustment was performed by logistic regression analysis. A probability of less than 0.05 was considered to be statistically significant.

\section{Results}

The clinicopathologic characteristics of all patients are summarized in Table 2. With regard to the histological types of these tumors, three were well-differentiated carcinoma, 12 were moderately differentiated carcinoma, 21 were poorly differentiated carcinoma, five were signet ring cell carcinoma, and one was mucinous carcinoma. Of the 42 gastric cancer patients, five were subsequently diagnosed with stage I, 10 with stage II, 17 with stage III, and 10 with stage IV. Nine patients were shown to have distant metastases, which were confirmed by chest X-ray, ultrasonography, computed tomography or magnetic resonance imaging.

Figure 1 shows the expression patterns of hTERT, CK-19, CK-20, and CEA mRNAs from blood samples of gastric cancer patients and healthy individuals by multiplex RT-PCR assay. In the multiplex RTPCR analysis of peripheral blood, the positive rates of hTERT, CK-19, CK-20, and CEA mRNA in gastric cancer patients were $61.9 \%$ (26/42), 69\% (29/42), $61.9 \%(26 / 42)$, and $78.6 \%$ (33/42), respectively (Table 3). However, only two of 30 healthy individuals were found to be positive for these molecular markers: one for CK-19 and the other for CK-20. We found that CEA mRNA expression was the most significant indicator for clinicopathologic characteristics and that it was closely correlated with tumor size $(p=0.008)$, vessel invasion ( $p=0.001)$, depth of tumor invasion ( $p=$ $0.007)$, lymph node metastasis $(p<0.001)$, and TNM stage $(p<0.001)$. However, no statistical significance was observed in the correlation between hTERT, CK19, and CK-20 mRNA expression and clinicopathologic characteristics of gastric cancer patients (ALL $p>0.05$ ). Table 4 shows that there was significant correlation between the expression of CEA mRNA and the occurrence of clinical metastases/recurrence postoperatively identified by multivariate analysis ( $p=$ 0.032 ). The gastric cancer patients with positive CEA 
Table 2

Clinicopathological characteristics of gastric cancer patients

\begin{tabular}{|c|c|}
\hline & Number of patients \\
\hline Total cases & 42 \\
\hline Age (yr) & $60.2 \pm 1.9$ \\
\hline$<60$ & 20 \\
\hline$\geqq 60$ & 22 \\
\hline \multicolumn{2}{|l|}{ Sex } \\
\hline Male & 24 \\
\hline Female & 18 \\
\hline \multicolumn{2}{|l|}{ Location } \\
\hline Cardia & 13 \\
\hline Body & 7 \\
\hline Antrum & 22 \\
\hline \multicolumn{2}{|l|}{ Tumor size } \\
\hline$<5 \mathrm{~cm}$ & 21 \\
\hline$\geqq 5 \mathrm{~cm}$ & 21 \\
\hline \multicolumn{2}{|l|}{ Differentiation } \\
\hline Well & 3 \\
\hline Moderate & 12 \\
\hline Poor & 21 \\
\hline Signet ring & 5 \\
\hline Mucinous & 1 \\
\hline \multicolumn{2}{|c|}{ Depth of tumor invasion } \\
\hline $\mathrm{T} 1$ & 5 \\
\hline $\mathrm{T} 2$ & 5 \\
\hline T3 & 28 \\
\hline $\mathrm{T} 4$ & 4 \\
\hline \multicolumn{2}{|c|}{ Lymph node metastasis } \\
\hline No & 11 \\
\hline Yes & 31 \\
\hline \multicolumn{2}{|l|}{ TNM stage } \\
\hline I & 5 \\
\hline II & 10 \\
\hline III & 17 \\
\hline IV & 10 \\
\hline \multicolumn{2}{|l|}{ Vessel invasion } \\
\hline Absent & 17 \\
\hline Present & 25 \\
\hline \multicolumn{2}{|c|}{ Distant metastasis } \\
\hline Absent & 33 \\
\hline Present & 9 \\
\hline
\end{tabular}

mRNA expression had a relative risk of 12.667 in developing postoperative recurrence/metastasis when compared with patients without CEA mRNA expression. Therefore, CEA mRNA expression is probably a significant and powerful predictor for the prognosis of patients with gastric cancer.

\section{Discussion}

Local recurrence and distant metastasis are major obstacles in the treatment of solid tumors. Mortality from gastric cancer is not primarily due to primary tumor lesion but the consequence of metastasis. The existence of occult metastasis in peripheral blood has been reported in human malignancies and is increas-
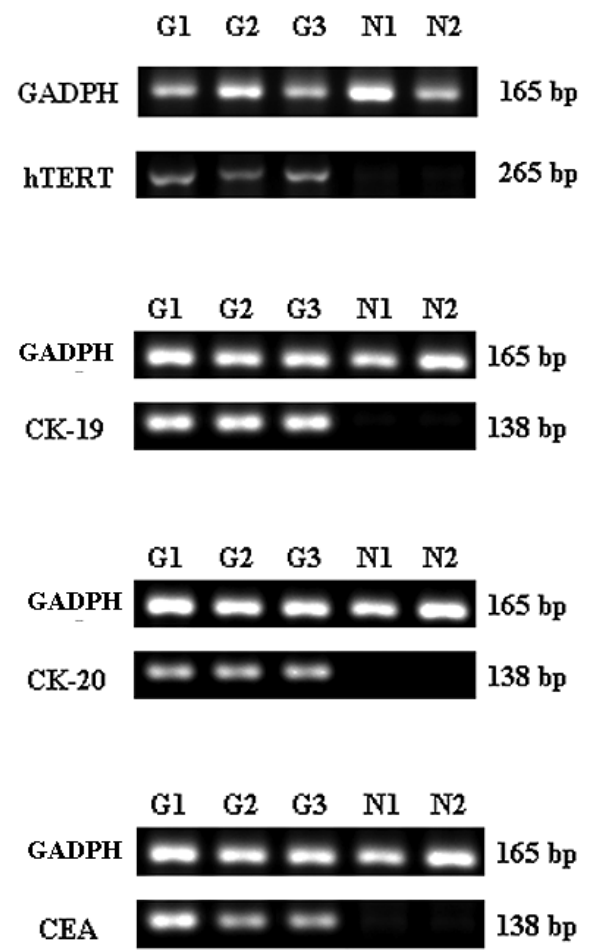

Fig. 1. Detection of hTERT, CK-19, CK-20, and CEA mRNAs by RT-PCR with the peripheral blood of gastric cancer patients. G: gastric cancer; N: healthy individual. GAPDH is an internal control.

ingly considered as a hallmark of cancer progression. In recent years, several molecular approaches have been assessed for their ability to detect various primary and recurrent cancers at an early stage. One of the newer areas under investigation is the use of RT-PCR to detect tumor-related gene mRNAs in disseminated tumor cells present in the blood of cancer patients $[6,13,17-$ 22]. Compared with samplings of bone marrow and lymph nodes, blood collection is a minimally invasive procedure and can be conducted throughout the course of the disease. The data presented here demonstrate the potential use of RT-PCR for the detection of circulating tumor cells in the peripheral blood of gastric cancer patients. To our knowledge, this is the first comprehensive report of simultaneous analysis including the correlation between hTERT, CK-19, CK-20, and CEA mRNA expression and clinicopathologic features of gastric cancer, including the comparison of superiority of these markers in predicting postoperative recurrence/metastasis for gastric cancer patients.

The current investigation has shown that the prevalence of hTERT, CK-19, CK-20, and CEA mRNA expression in peripheral blood of gastric cancer patients was $61.9 \%, 69 \%, 61.9 \%$ and $78.6 \%$, respectively. In 
Table 3

Correlations between the clinicopathological features and the mRNA expression of the markers studied

\begin{tabular}{|c|c|c|c|c|c|c|c|c|c|c|c|c|}
\hline & \multicolumn{2}{|c|}{ hTERT } & \multirow[b]{2}{*}{$\mathrm{P}$} & \multicolumn{2}{|c|}{ CK-19 } & \multirow[b]{2}{*}{$\mathrm{P}$} & \multicolumn{2}{|c|}{ CK-20 } & \multirow[b]{2}{*}{$\mathrm{P}$} & \multicolumn{2}{|c|}{ CEA } & \multirow[b]{2}{*}{$\mathrm{P}$} \\
\hline & + & - & & + & - & & + & - & & + & - & \\
\hline No. & 26 & 16 & & 29 & 13 & & 26 & 16 & & 33 & 9 & \\
\hline \multicolumn{13}{|l|}{ Age (yr) } \\
\hline$<60$ & 12 & 8 & 0.808 & 13 & 7 & 0.588 & 12 & 8 & 0.808 & 14 & 6 & 0.197 \\
\hline$\geqq 60$ & 14 & 8 & & 16 & 6 & & 14 & 8 & & 19 & 3 & \\
\hline \multicolumn{13}{|l|}{ Sex } \\
\hline Male & 14 & 10 & 0.582 & 15 & 9 & 0.289 & 15 & 9 & 0.927 & 20 & 4 & 0.385 \\
\hline Female & 12 & 6 & & 14 & 4 & & 11 & 7 & & 13 & 5 & \\
\hline \multicolumn{13}{|l|}{ Location } \\
\hline Cardia & 9 & 4 & 0.804 & 9 & 4 & 0.987 & 11 & 2 & 0.060 & 11 & 2 & 0.165 \\
\hline Body & 4 & 3 & & 5 & 2 & & 5 & 2 & & 7 & 0 & \\
\hline Antrum & 13 & 9 & & 15 & 7 & & 10 & 12 & & 15 & 7 & \\
\hline \multicolumn{13}{|l|}{ Tumor size } \\
\hline$<5 \mathrm{~cm}$ & 14 & 7 & 0.525 & 15 & 6 & 0.739 & 12 & 9 & 0.525 & 13 & 8 & 0.008 \\
\hline$\geqq 5 \mathrm{~cm}$ & 12 & 9 & & 14 & 7 & & 14 & 7 & & 20 & 1 & \\
\hline \multicolumn{13}{|l|}{ Differentiation } \\
\hline Well & 1 & 2 & 0.471 & 3 & 0 & 0.296 & 1 & 2 & 0.459 & 1 & 2 & 0.325 \\
\hline Moderate & 9 & 3 & & 7 & 5 & & 7 & 5 & & 9 & 3 & \\
\hline Poor & 13 & 8 & & 16 & 5 & & 14 & 7 & & 18 & 3 & \\
\hline Signet ring & 3 & 2 & & 2 & 3 & & 4 & 1 & & 4 & 1 & \\
\hline Mucinus & 0 & 1 & & 1 & 0 & & 0 & 1 & & 1 & 0 & \\
\hline \multicolumn{13}{|c|}{ Depth of tumor invasion } \\
\hline $\mathrm{T} 1$ & 3 & 2 & 0.217 & 3 & 2 & 0.676 & 3 & 2 & 0.709 & 1 & 4 & 0.007 \\
\hline $\mathrm{T} 2$ & 1 & 4 & & 3 & 2 & & 2 & 3 & & 4 & 1 & \\
\hline T3 & 19 & 9 & & 21 & 7 & & 18 & 10 & & 24 & 4 & \\
\hline $\mathrm{T} 4$ & 3 & 1 & & 2 & 2 & & 3 & 1 & & 4 & 0 & \\
\hline \multicolumn{13}{|c|}{ Lymph node metastasis } \\
\hline Absent & 6 & 5 & 0.559 & 9 & 2 & 0.286 & 6 & 5 & 0.559 & 3 & 8 & $<0.0001$ \\
\hline Present & 20 & 11 & & 20 & 11 & & 20 & 11 & & 30 & 1 & \\
\hline \multicolumn{13}{|l|}{ TNM stage } \\
\hline I & 2 & 3 & 0.179 & 4 & 1 & 0.932 & 2 & 3 & 0.661 & 1 & 4 & $<0.0001$ \\
\hline II & 6 & 4 & & 7 & 3 & & 6 & 4 & & 5 & 5 & \\
\hline III & 9 & 8 & & 11 & 6 & & 12 & 5 & & 17 & 0 & \\
\hline IV & 9 & 1 & & 7 & 3 & & 6 & 4 & & 10 & 0 & \\
\hline \multicolumn{13}{|l|}{ Vessel invasion } \\
\hline Absent & 8 & 9 & 0.102 & 12 & 5 & 0.859 & 9 & 8 & 0.324 & 9 & 4 & 0.688 \\
\hline Present & 18 & 7 & & 17 & 8 & & 17 & 8 & & 24 & 12 & \\
\hline \multicolumn{13}{|c|}{ Distant metastasis } \\
\hline Absent & 18 & 15 & 0.060 & 22 & 11 & 0.523 & 21 & 12 & 0.658 & 24 & 9 & 0.077 \\
\hline Present & 8 & 1 & & 7 & 2 & & 5 & 5 & & 9 & 0 & \\
\hline
\end{tabular}

our analysis, CEA mRNA expression seems to be a potential marker with the highest sensitivity for the detection of circulating tumor cells in gastric cancer patients. Mori and colleagues demonstrated that RT-PCR amplification of CEA mRNA is an efficient means of detecting circulating solid cancer cells in peripheral blood, and that gastrointestinal cancer may be better regarded as a systemic disease, even in early stages of carcinoma [23]. The prevalence of CEA mRNA expression in peripheral blood of gastric cancer patients in the literature varies considerably [11-15,24,25], but our detection rate seems to be markedly higher than that published in previous research. The difference could be explained by different populations for each stage in the experimental groups and the timing of sample col- lection [13,26]. Of our 42 patients, 27 (64.3\%) were diagnosed with stage III and IV gastric cancer, which might be one possible cause for a higher CEA mRNA detection rate. Mori et al. indicated that the positive detection rate for CEA mRNA in peripheral blood samples increased with the advanced stages of malignant disease [17]. Consistent with the findings of Mori et $a l$., our study disclosed that the detection rate for CEA mRNA in stage I, stage II, stage III, and stage IV was $20 \%, 50 \%, 100 \%$, and $100 \%$, respectively. Another possible reason for a higher detection rate for CEA mRNA might be that we collected the blood samples during gastric cancer surgery, which probably enhanced the molecular detection of circulating tumor cells by RT-PCR for CEA mRNA [26]. 
Table 4

mRNA molecular markers significantly associated with postoperative recurrence/metastasis using multivariate logistic regression analysis

\begin{tabular}{lccccc}
\hline Variables & $\beta$ & SE & $p$ value & Relative risk & 95\% confidence interval \\
\hline CEA mRNA & 2.539 & 1.186 & 0.032 & 12.667 & $1.240-129.363$ \\
\hline$\beta$ : coefficient; SE: standard error.
\end{tabular}

The research of Shin et al. suggested that hTERT mRNA in peripheral blood can be a potential molecular marker for gastric cancer with a positive detection rate of $46 \%$ [11]. In contrast, our results show that hTERT or cytokeratin mRNA is neither as sensitive as CEA mRNA for the detection of circulating tumor cells, nor as much of an independent predictor for postoperative surveillance in gastric cancer patients. Recently, CEA has been proposed as a more reliable marker than cytokeratins for the detection of disseminated tumor cells in peripheral blood of gastric cancer patients [14], which is also consistent with our findings. In addition, our observations pointed out that 19 of 33 patients with positive CEA mRNA expression subsequently developed postoperative metastasis/recurrence, while none of nine patients with negative CEA mRNA expression developed postoperative metastasis/recurrence (data not shown). The above findings are consistent with the conclusion of Noh et al., where positive CEA mRNA was demonstrated as possibly associated with early relapse in gastric cancer patients [27]. Due to our limited follow-up period, however, the clinical significance of positive CEA mRNA in peripheral blood should be further elucidated by a longitudinal follow-up with these patients or with a larger sample size in the future.

On the other hand, we detected two healthy individuals with positive molecular markers: one positive for CK-19 mRNA and one positive for CK-20 mRNA. The false positivity in healthy individuals might be attributed to the design of primers, contamination of epithelial cells, or handling of samples. Moreover, the CK-19 pseudogene might also interfere with RTPCR assays used to detect the micrometastatic tumor cells [28]. According to our previous study [29], c-met mRNA in the peripheral blood could be used potentially as a molecular marker for gastric cancer, and molecular markers are more advantageous than conventional serum CEA levels in postoperative surveillance. Therefore, the combined evaluation of both CEA mRNA and c-met mRNA expression in the peripheral blood may improve diagnostic accuracy for gastric cancer patients, especially for those negative for serum CEA.

In conclusion, our study indicates that the surveillance of gastric cancer by using CEA-specific RT-PCR to identify circulating tumor cells is feasible. This analysis can offer a simple, noninvasive, and promising tool for early detection of disseminated tumor cells in gastric cancer patients. The association between molecular detection of peripheral blood and a patient's longterm survival rate requires further study with a larger number of patients and a longer follow-up period.

\section{Acknowledgement}

This study was supported by a grant from the National Science Council (NSC91-2314-B-037-317), Republic of China.

\section{References}

[1] Department of Health, ed., Average Life Tables of TaiwanFuchien Area, The Republic of China, 2003, Department of Health, Taipei, 2004, 73-91.

[2] J.R. Siewert, K. Bottcher, J.D. Roder, R. Busch, P. Hermanek and H.J. Meyer, Prognostic relevance of systematic lymph node dissection in gastric carcinoma. German Gastric Carcinoma Study Group, Br J Surg 80 (1993), 1015-1018.

[3] Y. Ikeda, M. Mori, Y. Adachi, T. Matsushima, K. Sugimachi and M. Saku, Carcinoembryonic antigen (CEA) in stage IV gastric cancer as a risk factor for liver metastasis: a univariate and multivariate analysis, J Surg Oncol 53 (1993), 235-238.

[4] H. Furukawa, M. Hiratsuka, T. Iwanaga, S. Imaoka, O. Ishikawa, T. Kabuto, Y. Sasaki, M. Kameyama, H. Ohigashi, S. Nakamori, H. Nakano and T. Yasuda, Adjuvant chemotherapy for advanced gastric cancer, Nippon Geka Gakkai Zasshi (J Jpn Surg Soc) 97 (1996), 312-316.

[5] D. Palli, Epidemiology of gastric cancer: an evaluation of available evidence, J Gastroenterol 35(12) (2000), S84-S89.

[6] T.J. Pelkey, H.F. Frierson and D.E. Jr Bruns, Molecular and immunological detection of circulating tumor cells and micrometastases from solid tumors, Clin Chem 42 (1996), 13691381 .

[7] A. Abati and L.A. Liotta, Looking forward in diagnostic pathology: the molecular superhighway, Cancer 78 (1996), $1-3$.

[8] J.Y. Wang, J.S. Hsieh, C.C. Chen, W.S. Tzou, T.L. Cheng, F.M. Chen, T.J. Huang, T.S. Huang, S.Y. Huang, T. Yang and S.R. Lin, Alterations of the APC, c-met, and p53 Genes in Tumor Tissue and Serum of Patients with Gastric Cancers, $J$ Surg Res 120 (2004), 242-248.

[9] S. Nishida, K. Kitamura, D. Ichikawa, H. Koike, N. Tani and H. Yamagishi, Molecular detection of disseminated cancer cells in the peripheral blood of patients with gastric cancer, Anticancer Res 20 (2000), 2155-2159. 
[10] G.D. Sorenson, Detection of mutated KRAS2 sequences as tumor markers in plasma/serum of patients with gastrointestinal cancer, Clin Cancer Res 6 (2000), 2129-2137.

[11] J.H. Shin, J. Chung, H.O. Kim, Y.H. Kim, Y.M. Hur, J.H. Rhim, H.K. Chung, S.C. Park, J.G. Park and H.K. Yang, Detection of cancer cells in peripheral blood of stomach cancer patients using RT-PCR amplification of tumour-specific mRNAs, Aliment Pharmacol Ther 16(2) (2002), S137-S144.

[12] T. Majima, T. Ichikura, E. Takayama, K. Chochi and H. Mochizuki, Detecting circulating cancer cells using reverse transcriptase-polymerase chain reaction for cytokeratin mRNA in peripheral blood from patients with gastric cancer, Jpn J Clin Oncol 30 (2000), 499-503.

[13] P. Huang, J. Wang, Y. Guo and W. Xie, Molecular detection of disseminated tumor cells in the peripheral blood in patients with gastrointestinal cancer, J Cancer Res Clin Oncol 129 (2003), 192-198

[14] M. Ikeguchi, S. Ohro, Y. Maeda, K. Fukuda, K. Yamaguchi, H. Shirai, A. Kondo, S. Tsujitani and N. Kaibara, Detection of cancer cells in the peripheral blood of gastric cancer patients, Int J Mol Med 11 (2003), 217-221.

[15] H. Koike, D. Ichikawa, H. Ikoma, E. Otsuji, K. Kitamura and H. Yamagishi, Comparison of methylation-specific polymerase chain reaction (MSP) with reverse transcriptasepolymerase chain reaction (RT-PCR) in peripheral blood of gastric cancer patients, J Surg Oncol 15 (2004), 182-186.

[16] F.L. Greene, D.L. Page, I.D. Fleming, A.G. Fritz, C.M. Balch, D.G. Haller and M. Morrow, eds, AJCC Cancer Staging Handbook, Springer-Verlag, New York, 2001, 111-118.

[17] M. Mori, K. Mimori, H. Ueo, K. Tsuji, T. Shiraishi, G.F. Barnard, K. Sugimachi and T. Akiyoshi, Clinical significance of molecular detection of carcinoma cells in lymph nodes and peripheral blood by reverse transcription-polymerase chain reaction in patients with gastrointestinal or breast carcinomas, J Clin Oncol 16 (1998), 128-132.

[18] T. Taniguchi, M. Makino, K. Suzuki and N. Kaibara, Prognostic significance of reverse transcriptase-polymerase chain reaction measurement of carcinoembryonic antigen mRNA levels in tumor drainage blood and peripheral blood of patients with colorectal carcinoma, Cancer 89 (2000), 970-976.

[19] S. Nishida, K. Kitamura, D. Ichikawa, H. Koike, N. Tani and H. Yamagishi, Molecular detection of disseminated cancer cells in the peripheral blood of patients with gastric cancer, Anticancer Res 20 (2000), 2155-2159.

[20] A. Miyamoto, Y. Fujiwara, M. Sakon, H. Nagano, Y. Sugita, M. Kondo, H. Eguchi, K. Dono, K. Umeshita, S. Nakamori and
M. Monden, Development of a multiple-marker RT-PCR assay for detection of micrometastases of hepatocellular carcinoma, Dig Dis Sci 45 (2000), 1376-1382.

[21] S. Nakashima, S. Natsugoe, M. Matsumoto, F. Miyazono, A. Nakajo, K. Uchikura, K. Tokuda, S. Ishigami, M. Baba, S. Takao and T. Aikou, Clinical significance of circulating tumor cells in blood by molecular detection and tumor markers in esophageal cancer, Surgery 133 (2003), 162-169.

[22] Y. Mataki, S. Takao, K. Maemura, S. Mori, H. Shinchi, S. Natsugoe and T. Aikou, Carcinoembryonic antigen messenger RNA expression using nested reverse transcription-PCR in the peripheral blood during follow-up period of patients who underwent curative surgery for biliary-pancreatic cancer: longitudinal analyses, Clin Cancer Res 10 (2004), 3807-3814.

[23] M. Mori, K. Mimori, H. Ueo, N. Karimine, G.F. Barnard, K. Sugimachi and T. Akiyoshi, Molecular detection of circulating solid carcinoma cells in the peripheral blood: the concept of early systemic disease, Int J Cancer 68 (1996), 739-743.

[24] S. Sumikura, S. Ishigami, S. Natsugoe, F. Miyazono, K. Tokuda, A. Nakajo, H. Okumura, M. Matsumoto, S. Hokita and T. Aikou, Disseminated cancer cells in the blood and expression of sialylated antigen in gastric cancer, Cancer Lett 200 (2003), 77-83.

[25] X.M. Chen, G.Y. Chen, Z.R. Wang, F.S. Zhu, X.L. Wang and $\mathrm{X}$. Zhang, Detection of micrometastasis of gastric carcinoma in peripheral blood circulation, World J Gastroenterol 10 (2004), 804-808.

[26] F. Miyazono, S. Natsugoe, S. Takao, K. Tokuda, F. Kijima, K. Aridome, S. Hokita, M. Baba, Y. Eizuru and T. Aikou, Surgical maneuvers enhance molecular detection of circulating tumor cells during gastric cancer surgery, Ann Surg 233 (2001), 189_ 194.

[27] Y.H. Noh, G. Im, J.H. Ku, Y.S. Lee and M.J. Ahn, Detection of tumor cell contamination in peripheral blood by RT-PCR in gastrointestinal cancer patients, J Korean Med Sci 14 (1999), 623-628.

[28] P. Ruud, O. Fodstad and E. Hovig, Identification of a novel cytokeratin 19 pseudogene that may interfere with reverse transcriptase-polymerase chain reaction assays used to detect micrometastatic tumor cells, Int J Cancer 80 (1999), 119-125.

[29] J.Y. Wang, J.S. Hsieh, C.C. Chen, W.S. Tzou, T.L. Cheng, F.M. Chen, T.J. Huang, Y.S. Huang, S.Y. Huang, T. Yang and S.R. Lin, Alterations of APC, c-met, and p53 genes in tumor tissue and serum of patients with gastric cancers, J Surg Res 120 (2004), 242-248. 


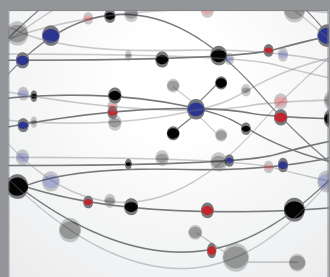

The Scientific World Journal
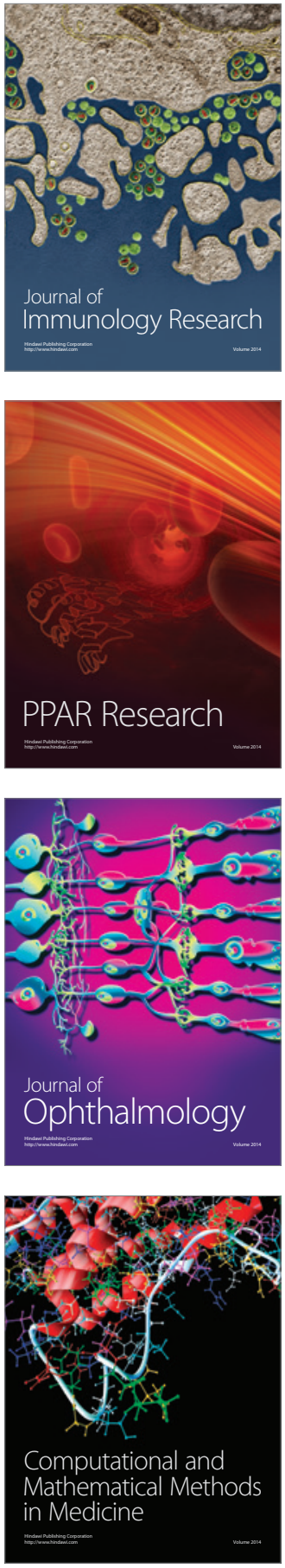

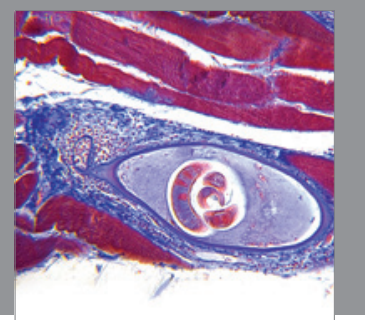

Gastroenterology

Research and Practice
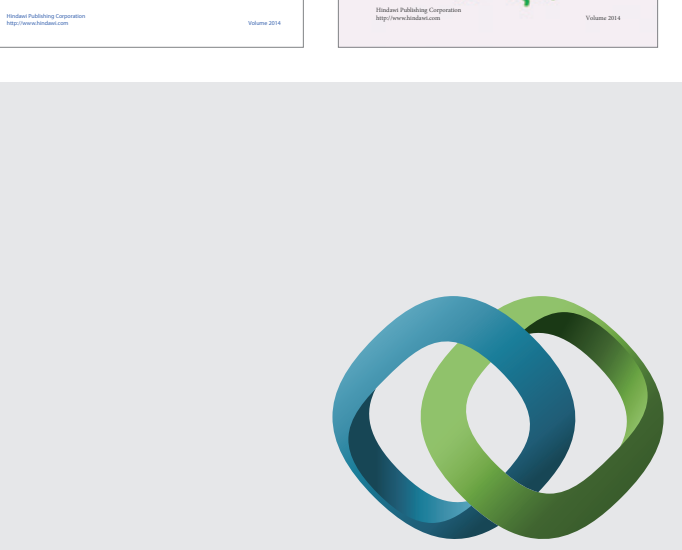

\section{Hindawi}

Submit your manuscripts at

http://www.hindawi.com
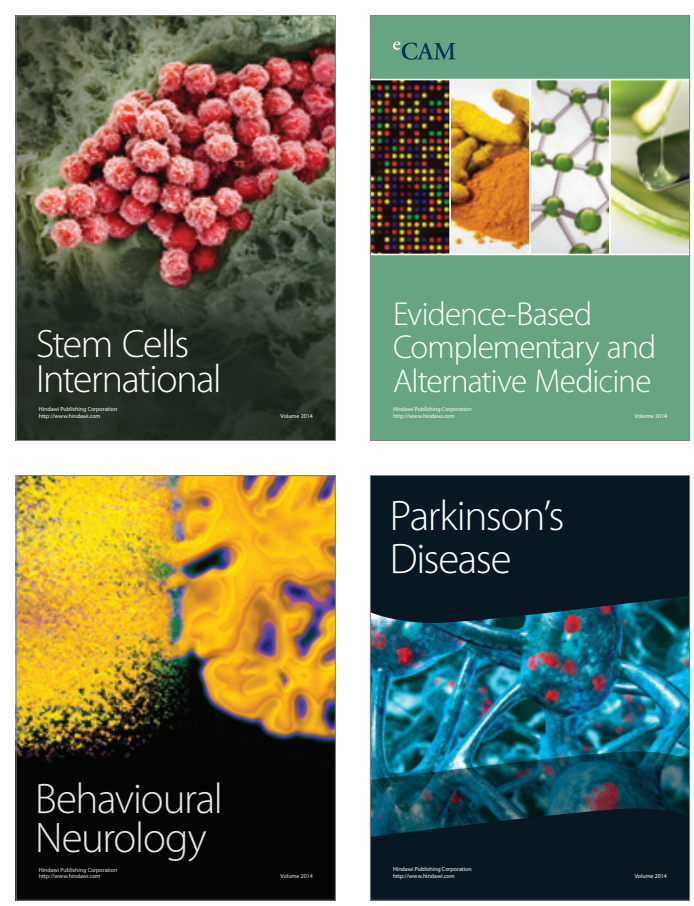

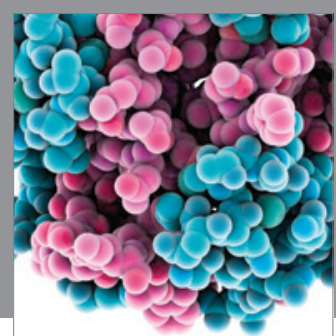

Journal of
Diabetes Research

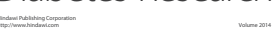

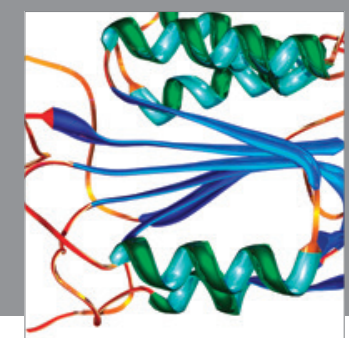

Disease Markers
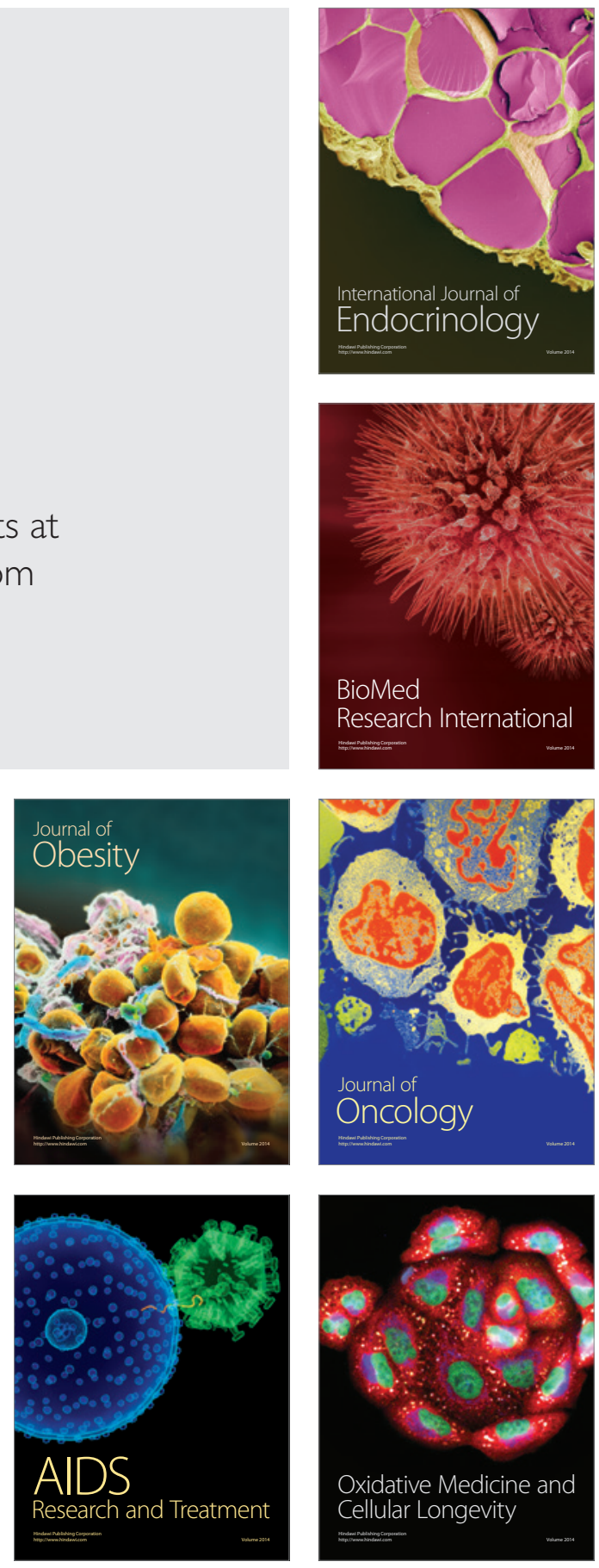